\title{
THE USE OF THE MULTIVARIATE STATISTICAL METHODS IN THE PERFORMANCE ANALYSIS OF NON-LIFE INSURANCE COMPANIES
}

\author{
HAYAT-DIŞI SIGGRTA ŞİRKETLERININN \\ PERFORMANS ANALIZİNDE ÇOK DEĞİŞKENLI ISTATISTIKKSEL \\ YÖNTEMLERIN KULLANIMI
}

\author{
Övgücan KARADAĞ ERDEMİR* \\ Hüseyin TATLIDILL ${ }^{* *}$
}

\begin{abstract}
Multivariate statistical methods have been used for performance analysis in recent years. Performance of companies in insurance sector, which is one of the important service industry, can be evaluated using multivariate statistical methods. In the present study, the performance of 30 non-life insurance companies operating in Turkey between 2010 and 2014 are analyzed by multivariate statistical methods such as Principal Component Analysis (PCA) and Multidimensional Scaling (MDS). Using the data in "Insurance and Private Pensions Reports" which are published by Republic of Turkey Prime Ministry Undersecretariat of Treasury Insurance Auditing Board at the end of each year, PCA and MDS analyzes are conducted. First PCA is carried out for each year then using the results of PCA, score values are calculated and insurance companies are ranked by these scores. Results of ranking are supported by rank correlation matrix. Performance of non-life insurance companies is investigated on the plane using MDS. Results of PCA, rank correlation and MDS are compared and interpreted.
\end{abstract}

Keywords: Non-Life Insurance Companies, Financial Performance, Principal Component Analysis, Rank Correlation, Multidimensional Scaling.

Jel Codes: C38, G14, G22

* Research Assistant, Hacettepe University, Department of Actuarial Science, ovgucan@hacettepe.edu.tr

** Professor, Hacettepe University, Department of Statistics, htatlidil@yahoo.com 


\section{Öz}

Çok değişkenli istatistiksel yöntemler son yıllarda performans analizi için kullanılmaktadır. Önemli hizmet sektörlerinden biri olan sigorta sektöründeki şirketlerin performansı çok değişkenli istatistiksel yöntemlerle değerlendirilebilir. Bu çalışmada, 2010-2014 yılları arasında Türkiye'de faaliyet gösteren 30 hayat-dışı sigorta şirketinin performansı, Temel Bileşen Analizi (TBA) ve Çok Boyutlu Ölçekleme (ÇBÖ) gibi çok değişkenli istatistiksel yöntemler ile analiz edilmiştir. Türkiye Cumhuriyeti Başbakanlık Hazine Müsteşarlığ 1 Sigorta Denetim Kurulu tarafından her yılın sonunda yayınlanan "Sigorta ve Bireysel Emeklilik Raporları'ndaki veriler kullanarak TBA ve ÇBÖ analizleri yapılmıştır. İlk olarak her yıl için TBA yapılmış, daha sonra TBA sonuçları kullanılarak skor değerleri hesaplanmış ve sigorta şirketleri bu skorlara göre sıralanmıştır. Sıralama sonuçları sıra korelasyon matrisiyle desteklenmiştir. Hayat-dışı sigorta şirketlerinin performansı ÇBÖ kullanılarak düzlemde incelenmiştir. TBA, sıra korelasyonu ve ÇBÖ sonuçları karşılaştırılmış ve yorumlanmıştır.

Anahtar Kelimeler: Hayat-Dışı Sigorta Şirketleri, Finansal Performans, Temel Bileşen Analizi, Sıra Korelasyonu, Çok Boyutlu Ölçekleme.

Jel Kodları: C38, G14, G22

\section{Introduction}

In insurance sector, which is one of the important service industry, insurances are generally separated into groups such as non-life, life, pension and reinsurance. Most of premium production in Turkey arises from non-life insurance premium production according to the annual "Insurance and Private Pensions Reports" which are published by Republic of Turkey Prime Ministry Undersecretariat of Treasury Insurance Auditing Board. According to reports, insurance and pension companies generated TL 14.1 billion total premium in 2010. Non-life insurance branches accounted for nearly 85\% of total premiums (TL 11.9 billion) whereas life insurance branches accounted for 15\% (TL 2.1 billion). Insurance and pension companies generated TL 25.9 billion total premium in 2014 . Non-life insurance branches accounted for nearly $\% 88$ of total premiums (TL 22.7 billion) whereas life insurance branches accounted for $12 \%$ (TL 3.2 billion). Ratios of non-life insurance premium production in the total premium production are higher than ratios of life insurance premium production in the total premium production also for 2011, 2012 and 2013. Premium productions are TL 17.6 billion, TL 19.8 billion and TL 24.2 billion while non-life premium productions are TL 14.5 billion, TL 17.1 billion and TL 20.8 billion for years 2011, 2012 and 2013 respectively. As is seen from the reports total premium production and non-life premium production have increased over the years.

Therefore, efficiencies of non-life insurance companies are important. The performances of the non-life insurance companies vary from company to company. Some companies have been active in a long period by using their resources efficiently, while the other companies use their resources ineffectively and show a weak performance by the wrong management policies. Information about companies are given briefly in the "Application" part of the study. The detailed information about the companies are submitted at the section of Tables of the annual "Insurance and Private Pensions Reports". 


\section{Literature}

An incomprehensive performance analysis can be conducted by technical profit and loss information in the activity reports. However, mathematical methods are needed for more comprehensive performance analysis. Performance of insurance companies can be evaluated using multivariate statistical methods. Multivariate statistical methods have been used for performance analysis in recent years.

Mostly used multivariate method for efficiency analysis is data envelopment analysis (DEA) (Hao and Chou, 2005; Tone and Sahoo, 2005; Yang, 2006; Harton, 2010). This nonparametric method have a very wide field of use such as performance of insurance companies, banks, hospitals, universities, factories, financial instruments, etc.

Principal component analysis (PCA) which is actually one of the data reduction method for other analysis can be used as a measurement method (Zhu, 1998; Wang and Du, 2000; Zhongsheng and Dong, 2008; Ho and Wo, 2009; Mashhadifarahani et al., 2013).

Zhu (1998) compared economic performance of Chinese cities using PCA and DEA, then yield consistent and mutually complementary results. Wang and Du (2000) used PCA to transform the high-dimensional problems into lower dimensional problems. They used PCA for analysis of correlated multivariate non-normal data. Zhongsheng and Dong (2008) used PCA to operate efficiency of commercial banks between 1999 and 2003. Ho and Wo (2009) presented a hybrid approach to evaluate performance of internet banking by using PCA and DEA. Mashhadifarahani et al. (2013) presented a combined principal component analysis-regression analysis model to show effects of bad loans on the economic performance of banking systems.

There are some studies comparing DEA and PCA as methods of performance measurement. (Zhu, 1998; Shanmugam and Johnson, 2007). Except these two methods, there are other methods that are used for performance analysis such as non-hierarchical cluster analysis, tobit regression model, stochastic frontier and the Malmquist total factor productivity.

In this study, the performance of 30 non-life insurance companies operating in Turkey between 2010 and 2014 are analyzed by multivariate statistics methods such as PCA and Multidimensional Scaling (MDS) using the data in "Insurance and Private Pensions Reports". First PCA is carried out for each year then using the results of PCA, score values are calculated and insurance companies are ranked by these scores. Results of ranking are supported by rank correlation matrix. Efficiency of non-life insurance companies is investigated on the plane using MDS.

This paper is organized as follows: multivariate statistical methods that are used in this study are explained in Section 1. A numerical study in which compared Turkish non-life insurance companies by the methods which mentioned in previous section are given in Section 2 and concluding remarks are provided in Section 3. 


\section{Multivariate Statistical Methods}

Multivariate analysis is one of the important branches of statistics and multivariate statistical methods are used for simplification, data reduction, classification, correlation analysis, ranking and scaling (Tatlidil, 2002). There are many multivariate statistical methods such as PCA, MDS, factor analysis, canonic correlation analysis, discriminant analysis, logistic regression analysis, clustering analysis and multivariate regression analysis, however only two of them are used in this study. PCA and MDS are given briefly as follows.

\section{I. Principal Component Analysis}

In multivariate statistical analysis, $\mathrm{p}$ variables (properties) are investigated for $\mathrm{n}$ individuals (objects). Some of these variables (properties) can be highly correlated each other and the number of $\mathrm{p}$ can be very large, therefore some problems in the analyses can arise. Working with a large number of variables is not desirable as it will impair the assumption of independence between variables, it will also increase the computational burden and cause some difficulties in calculations. PCA is a multivariate statistical method, which is generally, used in the destruction of the structure of dependence between variables and the reduction of the number of variables in other word the dimension reduction or the data reduction. It is also used as a data preparation technique for other analyses (Tatlıdil, 2002). The principal components are obtained as a linear combination of the original variables, therefore new components contain specific information from all variables.

Matrix $Y_{p x n}$ comprise of the multiplication of transformation matrix $T_{p x p}$ and matrix $X_{p x n}$ $X_{p x n}$. Standardized matrix $Z_{p x n}$ is used instead of matrix $X_{p x n}$ if the units of measurement of the decision-making units are different from each other.

$$
Y_{p x n}=T_{p x p}^{\prime} Z_{p x n}
$$

After transformation, independent $y_{i j}$ 's are obtained from dependent $z_{i j}$ 's. The mean vector and the covariance matrix of $Y_{p x n}$ are given as follows,

$$
\begin{aligned}
& E\left(Y_{p x n}\right)=E\left(T_{p x p}^{\prime} Z_{p x n}\right)=T_{p x p}^{\prime} E\left(Z_{p x n}\right)=0 \\
& \operatorname{Var}\left(Y_{p x n}\right)=T_{p x p}^{\prime} E\left(Z_{p x n} Z_{p x n}^{\prime}\right) T_{p x p}=T_{p x p}^{\prime} R_{p x p} T_{p x p}
\end{aligned}
$$

Matrix $R_{p x p}$ is the correlation matrix between variables. In order to the vectors of the transformed $Y_{p x n}$ to be vertical to each other, the matrix $\operatorname{Var}\left(Y_{p x n}\right)$ should be diagonal. Where $\lambda_{1}$ $\lambda_{1}$ is the eigenvalue of $\mathbf{R}$ matrix and the eigenvalue $\lambda_{1}$ is obtained from equation $|R-\lambda I|=0$. $p$ and $\lambda$ values are calculated from the equation. Using obtained eigenvalues and eigenvector some matrix calculations that are given in detailed form by Tatlidil (2002) are conducted systematically and $\sum_{j=1}^{p} \lambda_{j}=p$ is obtained (Tatlidil, 2002).

It is important to decide on the number of components in a PCA study. Many methods and approaches have been developed for this purpose; however, the simplest and most used of them 
is the summation of $\lambda \lambda$ values up to $2 / 3$ of the total variation. $k$ shows the number of new (principal) components and there should be an equation as follows (Rencher, 2002),

$$
\frac{\sum_{j=1}^{k} \lambda_{j}}{\sum_{j=1}^{p} \lambda_{j}}=\frac{2}{3}, \quad k=1,2,3, \ldots ., p .
$$

In this study, PCA is used as a method of measuring performance by some score values that are calculated according to results of PCA.

\subsection{Multidimensional Scaling}

MDS is a technique that creates a map displaying the relative positions of objects, given only a table of the distances between them. In this analysis distance matrix $\boldsymbol{D}$ is used instead of data matrix $X$. The main purpose of MDS is composing the structure of the objects as close as possible to the original shape with as few dimensions as possible using the values of distance. Generally Euclidean distances are used in MDS, however if there are asymmetric distances other distance criteria can be used. MDS is included among the $\mathrm{Q}$ analyzes such as clustering analysis, besides it can be taken as a $\mathrm{R}$ analysis technique such as principal component analysis due to the metric scaling methods. More details about the steps for metric and non-metric scaling can be found in Tatlıdil (2002). Using MDS, units can be classified according to similar properties and these classes can be used for other calculations.

In this study using results of PCA, non-life insurance companies are ranked. Rank values are interpreted by the help of rank correlation matrix. Rank correlation is not a multivariate method but it is used as a supportive to evaluate the performance of non-life insurance companies. Rank correlation coefficient measures the degree of similarity between two rankings and can be used to assess the significance of the relation between them. Both correlation between score values, which are calculated by results of PCA, and correlation between rank values from 2010 to 2014 are analyzed. Pearson's correlation coefficients are calculated for score values, while Spearman's rho correlation coefficients are calculated for rank values. The Pearson's correlation coefficient is a measure of association for linear relationship, whereas the Spearman's rho correlation measures the strength and direction of association between two ranked variables (Denuit et al., 2006). The Spearman's rank-order correlation is the nonparametric version of the Pearson product-moment correlation and it can be used when the assumptions of the Pearson's correlation are violated. Rank values are more rational for comparison because ranking companies enable to interpret using the same scale. Furthermore, values of rank correlation coefficient are bigger than values of score correlation coefficient as it can be seen in the application part of study. Numerical values will be given in Section 2.

\section{Application: Comparison of Turkish Non-Life Insurance Companies}

In this study, data in the "Insurance and Private Pension Activities Reports in Turkey" which was published by Republic of Turkey Prime Ministry Undersecretariaty of Treasury in the years 
2010-2014 is used. Using the information in these reports, changes of life, non-life and total premium production between the years 2010-2014 are shown in the following chart.

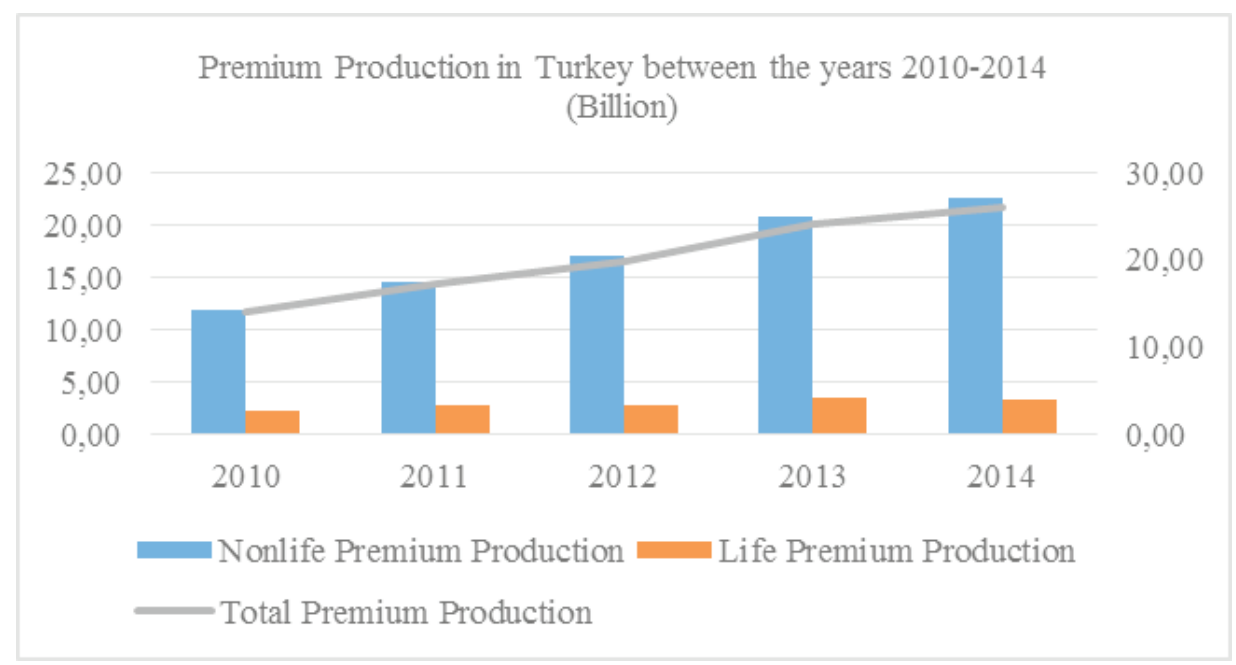

Figure I: Premium Production in Turkey between the Years 2010-2014

Premium production follows an increasing line from 2010 to 2014 . It can be shown that this increment is derived from the non-life insurance premium production. The non-life insurance sector is more developed than the life insurance sector in Turkey. Non-life insurance companies that are active in Turkey during five year are investigated and it is noticed there are 30 non-life insurance companies operating in Turkey from the year 2010 to year 2014. These non-life insurance companies are Ace, Aksigorta, Allianz, Anadolu, Ankara, Atradius, Aviva, Axa, Bnp Cardif, Coface, Demir, Dubai Star, Ergo, Euler Hermes, Eureko, Generali, Groupama, Güneş, Halk, Hdi, Işık, Liberty, Mapfre, Neova, Ray, Sbn, Sombo Japan, Türk Nippon, Ziraat and Zurich.

In this study performance of non-life insurance companies operating in Turkey between year 2010 and 2014 is analyzed by multivariate statistical methods such as PCA and MDS. Results of multivariate methods are supported by rank correlation matrix. Variables are determined according to previous studies and they are given as following.

\section{I. Variables}

There are many variables, which effect the performance of an insurance company. According to research of literature review, ten variables are selected among commonly used variables and their formulas are given as follows. Most of the variables are financial ratios, however some transformations are applied to non-financial ratio variables. 


\section{Returns on Assets (ROA)}

In previous studies, generally ROA has been used for dependent variables as the performance criterion. ROA is taken as independent variable in this study. ROA can be calculated as follows,

ROA $=\frac{\text { Net Profit }}{\text { Total Assets }}$

\section{Gross Written Premiums (GWP)}

This variable is formed as taking logarithm of total gross premium. Logarithmic transformation eliminates the extreme values in data.

$$
\text { GWP }=\log (\text { Total Gross Premium })
$$

\section{Company Size (CS)}

This variable is formed as taking logarithm of total assets. The reason of logarithmic transformation is the same as for GWP.

$$
C S=\log (\text { Total Assets })
$$

Insurance Leverage Ratio (ILR)

$$
I L R=\frac{\text { Net Technical Provisions }}{\text { Shareholder s'Equity }}
$$

\section{Expense-Revenue Ratio (ERR)}

This ratio is an alternative ratio to loss ratio, which is calculated by dividing incurred claims to earned premiums.

$$
E R R=\frac{\text { Expenses }}{\text { Net Revenue }}
$$

\section{Market Share (MS)}

This variable is a percentage value and is taken from the "Insurance and Private Pension Activities Reports in Turkey" directly.

\section{Current Ratio (CR)}

$$
\begin{aligned}
& C R=\frac{\text { Total Current Assets }}{\text { Total Short Term Liabilities }} \\
& \text { Equity-Asset Ratio (EAR) } \\
& E A R=\frac{\text { Total Shareholder s'Equity }}{\text { Total Assets }}
\end{aligned}
$$


Premium-Asset Ratio (PAR)

PAR $=\frac{\text { Total Premium Production }}{\text { Total Assets }}$

Returns on Equity (ROE)

$$
R O E=\frac{\text { Net Profit }}{\text { Total Shareholder s'Equity }}
$$

Determination of variables is one of the most important issue for a performance analysis. Results and ranking can be change according to variables. To investigate the significance of variables linear regression analyses are conducted for each year. Significant variables change year to year but linear models are significant with ten variables for all year. Hence, it is assumed that ten variables are significant for five-year period and analyses are conducted using all of ten variable.

\subsection{Five-Year Performance Analysis of Non-Life Insurance Companies via Multivariate Statistical Methods}

\subsection{Principal Component Analysis}

PCA, which is actually a data reduction method, is used as an effectiveness measurement method in this study. Using the results of PCA, new scores are calculated for five years. These scores are calculated as a weighted average of new components and the percentages values of "Extraction Sums of Squared Loadings of Variance" are taken as weights. Linear equations for five year are as follows. $y_{i}$ 's show the principal components, $a_{i}$ 's are the weights and index $i$ is valued from 1 to number of principal components (n). $z_{j}$ 's are the new score values and the general form for new components are $z_{j}=a_{1} y_{1}+a_{2} y_{2}+\cdots+a_{n} y_{n}$ where $\mathrm{j}=2010, \ldots, 2014$.

Table I: PCA Score Values of Turkish Non-Life Insurance Companies between 2010 and 2014

\begin{tabular}{|l|l|l|}
\hline Year & Linear Equation for New Score Value & $\begin{array}{l}\text { Number of Principal Com- } \\
\text { ponents (n) }\end{array}$ \\
\hline 2010 & $z_{2010}=0.500 y_{1}+0.275 y_{2}+0.125 y_{3}$ & 3 \\
\hline 2011 & $z_{2011}=0.371 y_{1}+0.238 y_{2}+0.210 y_{3}$ & 3 \\
\hline 2012 & $z_{2012}=0.390 y_{1}+0.258 y_{2}+0.200 y_{3}$ & 3 \\
\hline 2013 & $z_{2013}=0.367 y_{1}+0.291 y_{2}+0.127 y_{3}+0.121 y_{4}$ & 4 \\
\hline 2014 & $z_{2014}=0.369 y_{1}+0.294 y_{2}+0.129 y_{3}$ & 3 \\
\hline
\end{tabular}

Decision-making units are non-life insurance companies in this study, therefore for year $i$ there are $30 z_{j}$ values. Using the linear equations in Table 1, score values are calculated for 30 companies in Table 2 as follows. 
Table 2. PCA Score Values of Turkish Non-Life Insurance Companies between 2010 and 2014

\begin{tabular}{|l|l|l|l|l|l|}
\hline & $\mathbf{2 0 1 0}$ & $\mathbf{2 0 1 1}$ & $\mathbf{2 0 1 2}$ & $\mathbf{2 0 1 3}$ & $\mathbf{2 0 1 4}$ \\
\hline Ace & -0.41 & -0.32 & -0.64 & -0.72 & -0.54 \\
\hline Aksigorta & 0.61 & 0.49 & 0.64 & 0.50 & 0.51 \\
\hline Allianz & 0.68 & 0.49 & 0.67 & 0.75 & 1.00 \\
\hline Anadolu & 0.91 & 0.75 & 0.82 & 0.85 & 0.94 \\
\hline Ankara & 0.06 & 0.03 & -0.02 & 0.02 & -0.09 \\
\hline Atradius & -0.76 & -0.53 & -1.53 & -0.89 & -1.22 \\
\hline Aviva & 0.16 & 0.14 & 0.03 & 0.12 & -0.04 \\
\hline Axa & 0.99 & 0.72 & 0.29 & 1.08 & 0.98 \\
\hline Bnp-Cardif & -0.50 & -0.11 & -0.58 & -0.72 & -0.51 \\
\hline Coface & -0.44 & -0.21 & -0.54 & -0.34 & -0.45 \\
\hline Demir & -0.55 & -0.26 & -0.47 & -0.66 & -0.29 \\
\hline Dubai & -0.14 & -1.17 & -0.51 & -0.17 & 0.08 \\
\hline Ergo & 0.50 & 0.35 & 0.25 & 0.01 & -0.29 \\
\hline Euler-Her. & -2.07 & -0.92 & -0.39 & -0.65 & 0.02 \\
\hline Eureko & 0.42 & 0.38 & 0.33 & 0.13 & -0.06 \\
\hline Generali & -0.13 & -0.18 & -0.22 & -0.53 & 0.05 \\
\hline Groupama & 0.48 & 0.5 & 0.44 & 0.24 & 0.46 \\
\hline Gunes & 0.52 & 0.36 & 0.54 & 0.35 & 0.34 \\
\hline Halk & 0.00 & -0.03 & 0.29 & 0.14 & 0.13 \\
\hline Hdi & 0.06 & 0.10 & 0.14 & 0.08 & -0.53 \\
\hline Isik & -0.08 & 0.07 & 0.00 & -0.17 & -0.22 \\
\hline Liberty & -0.24 & -0.1 & -0.42 & -0.39 & -0.29 \\
\hline Mapfre & 0.24 & 0.47 & 0.46 & 0.39 & 0.49 \\
\hline Neova & -0.22 & -0.20 & 0.06 & 0.17 & 0.01 \\
\hline Ray & 0.13 & 0.09 & 0.21 & 0.10 & 0.02 \\
\hline Sbn & -0.07 & -1.26 & -0.1 & 0.49 & -0.32 \\
\hline Sompo Jap. & 0.19 & 0.21 & 0.29 & 0.15 & 0.21 \\
\hline Turk Nipp. & -0.48 & 0.05 & -0.6 & -0.70 & -0.48 \\
\hline Ziraat & 0.05 & 0.01 & 0.4 & 0.08 & -0.05 \\
\hline Zurich & 0.10 & 0.09 & 0.15 & 0.28 & 0.16 \\
\hline & & & & \\
\hline
\end{tabular}

These score values do not make sense with these forms. However, the score values are correlated with each other from year to year according to correlation matrix which is given in Table 3 . Hence, companies can be ranked using these score values and rational results can be obtained.

Table 3: Correlation Matrix of Score Values (Pearson)

\begin{tabular}{|l|l|l|l|l|l|}
\hline & $\mathbf{2 0 1 0}$ & $\mathbf{2 0 1 1}$ & $\mathbf{2 0 1 2}$ & $\mathbf{2 0 1 3}$ & $\mathbf{2 0 1 4}$ \\
\hline $\mathbf{2 0 1 0}$ & 1.000 & 0.730 & 0.740 & 0.810 & 0.629 \\
\hline $\mathbf{2 0 1 1}$ & 0.730 & 1.000 & 0.673 & 0.544 & 0.565 \\
\hline $\mathbf{2 0 1 2}$ & 0.740 & 0.673 & 1.000 & 0.851 & 0.814 \\
\hline $\mathbf{2 0 1 3}$ & 0.810 & 0.544 & 0.851 & 1.000 & 0.814 \\
\hline $\mathbf{2 0 1 4}$ & 0.629 & 0.565 & 0.814 & 0.814 & 1.000 \\
\hline
\end{tabular}


Rank values for 30 companies between 2010 and 2014 are given in Table 4. PCA is used to calculate new score values and companies are ranked using these score values. Rank values are correlated with each other from year to year according to correlation matrix, which is given in Table 5 .

Table 4: Rank Values of Turkish Non-Life Insurance Companies between 2010 and 2014

\begin{tabular}{|c|c|c|c|c|c|c|}
\hline & 2010 & 2011 & 2012 & 2013 & 2014 & Average of 5 Years \\
\hline Ace & 24 & 26 & 29 & 29 & 29 & 27.40 \\
\hline Aksigorta & 4 & 5 & 3 & 4 & 4 & 4.000 \\
\hline Allianz & 3 & 4 & 2 & 3 & 1 & 2.600 \\
\hline Anadolu & 2 & 1 & 1 & 2 & 3 & 1.800 \\
\hline Ankara & 14 & 17 & 19 & 18 & 19 & 17.40 \\
\hline Atradius & 29 & 27 & 30 & 30 & 30 & 29.20 \\
\hline Aviva & 11 & 11 & 17 & 14 & 16 & 13.80 \\
\hline Axa & 1 & 2 & 10 & 1 & 2 & 3.200 \\
\hline Bnp-Cardif & 27 & 21 & 27 & 28 & 27 & 26.00 \\
\hline Coface & 25 & 24 & 26 & 22 & 25 & 24.40 \\
\hline Demir & 28 & 25 & 24 & 26 & 22 & 25.00 \\
\hline Dubai & 21 & 29 & 25 & 21 & 11 & 21.40 \\
\hline Ergo & 6 & 9 & 12 & 19 & 23 & 13.80 \\
\hline Euler-Her. & 30 & 28 & 22 & 25 & 14 & 23.80 \\
\hline Eureko & 8 & 7 & 8 & 13 & 18 & 10.80 \\
\hline Generali & 20 & 22 & 21 & 24 & 12 & 19.80 \\
\hline Groupama & 7 & 3 & 6 & 9 & 6 & 6.200 \\
\hline Gunes & 5 & 8 & 4 & 7 & 7 & 6.200 \\
\hline Halk & 17 & 19 & 9 & 12 & 10 & 13.40 \\
\hline Hdi & 15 & 12 & 15 & 16 & 28 & 17.20 \\
\hline Isik & 19 & 15 & 18 & 20 & 20 & 18.40 \\
\hline Liberty & 23 & 20 & 23 & 23 & 21 & 22.00 \\
\hline Mapfre & 9 & 6 & 5 & 6 & 5 & 6.200 \\
\hline Neova & 22 & 23 & 16 & 10 & 15 & 17.20 \\
\hline Ray & 12 & 14 & 13 & 15 & 13 & 13.40 \\
\hline Sbn & 19 & 30 & 20 & 5 & 24 & 19.60 \\
\hline Sompo Jap. & 10 & 10 & 11 & 11 & 8 & 10.00 \\
\hline Turk Nipp. & 26 & 16 & 28 & 27 & 26 & 24.60 \\
\hline Ziraat & 16 & 18 & 7 & 17 & 17 & 15.00 \\
\hline Zurich & 13 & 13 & 14 & 8 & 9 & 11.40 \\
\hline
\end{tabular}

According to Table 4, the companies with the best performance are Anadolu, Allianz, Axa and Aksigorta while the companies, which have the most unsuccessful performance, are Atradius, 
Bnp-Cardif, Demir, Turk Nippon and Coface. Stable companies for five years are Aksigorta, Anadolu, Atradius, Liberty, Ray and Sompo Japan while unstable companies are Axa, Ergo, Euler and Sbn. Ranking values of Aksigorta, Anadolu, Atradius, Liberty, Ray and Sompo Japan in five years has not changed too much and ranking values are close to average value. Axa (especially after 2012) and Euler Hermes are developing companies, while Ergo is falling down year by year. Sbn is unstable by reason of changes in it's ranking.

It can be shown that there is a significant correlation between ranking values from first year (2010) to last year (2014) by the help of rank correlation matrix in Table 5. According to this rank correlation matrix the highest correlation is 0,898 between 2010 and 2011 while the lowest correlation is 0.635 between 2010 and 2014. It is rational that the correlations between consecutive years are high.

Table 5: Rank Correlation Matrix of Rank Values (Spearman's Rho)

\begin{tabular}{|l|l|l|l|l|l|}
\hline & $\mathbf{2 0 1 0}$ & $\mathbf{2 0 1 1}$ & $\mathbf{2 0 1 2}$ & $\mathbf{2 0 1 3}$ & $\mathbf{2 0 1 4}$ \\
\hline 2010 & 1.000 & 0.898 & 0.886 & 0.842 & 0.717 \\
\hline 2011 & 0.898 & 1.000 & 0.821 & 0.693 & 0.635 \\
\hline 2012 & 0.886 & 0.821 & 1.000 & 0.854 & 0.782 \\
\hline 2013 & 0.842 & 0.693 & 0.854 & 1.000 & 0.776 \\
\hline 2014 & 0.717 & 0.635 & 0.782 & 0.776 & 1.000 \\
\hline
\end{tabular}

Changes of rank values of companies from year to year can be seen by the graph that is given by Figure 2. Comments for Table 5 are supported by the graph in Figure 2. Stability of companies can be seen clearly from Figure 2 that show ranking of Turkish non-life insurance companies between 2010 and 2014 .

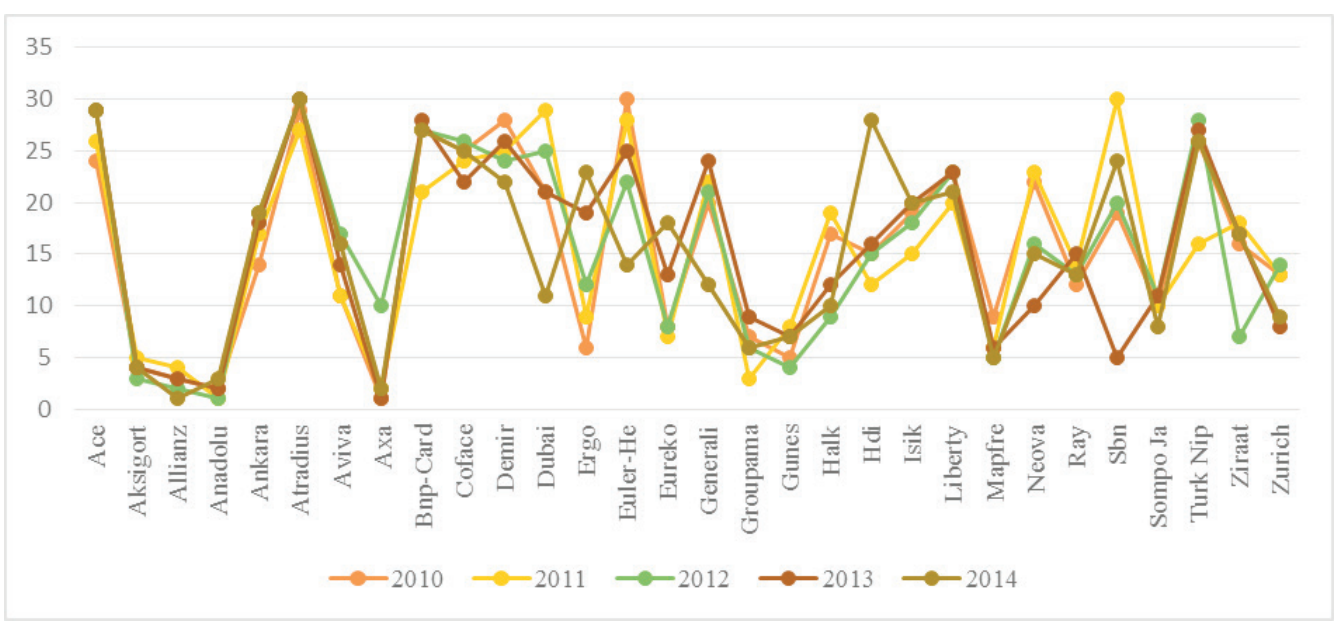

Figure 2: Ranking of Turkish Non-life Insurance Companies between 2010 and 2014 


\subsubsection{Multidimensional Scaling Analysis}

Locations of companies relative to each other are investigated by MDS after PCA supported by rank correlation. MDS is conducted for five year but only graphs for first and last year are given in this study, the others can be interpreted similarly. Figure 3 and Figure 4 give the MDS graphs for year 2010 and 2014 respectively.

Derived Stimulus Configuration

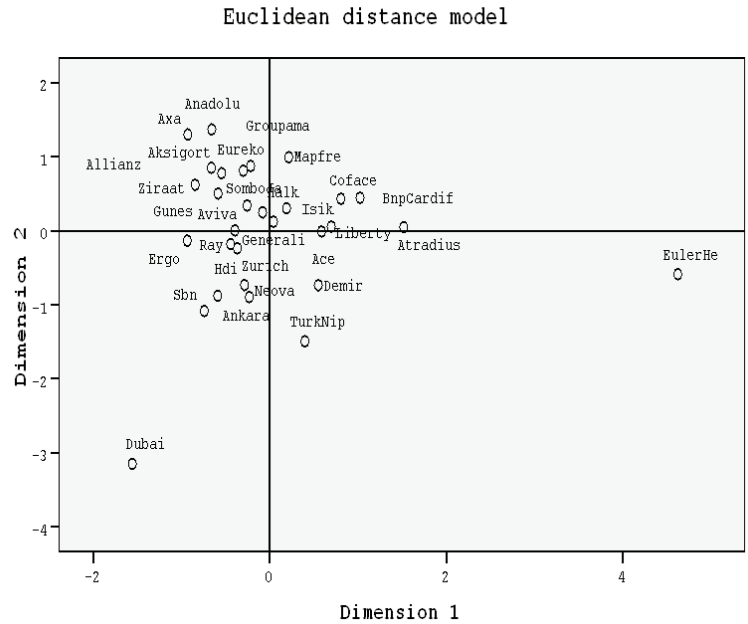

Figure 3: MDS of 30 Turkish Non-life Insurance Companies in 2010

Companies are positioned by dimensional 1 (horizontal axis) and dimensional 2 (vertical axis). Financial ratios included in dimensions can be explained by results of PCA. Euler Hermes is the company with most unsuccessful performance in 2010. Dubai and Euler Hermes are in a farther position from other companies. Dubai is not the worst company in 2010, but it is also far away from the others. The reason of this is explanation ratios of dimensions. First dimension explains $50 \%$ and the second one $27 \%$ of changes in performance according to PCA. Both of companies show an increase in five-year period. Successful companies such as Axa, Anadolu, Aksigorta and Allianz are at same location according to Figure 3 that show the MDS graph for 2010. 
Derived stimulus Configuration

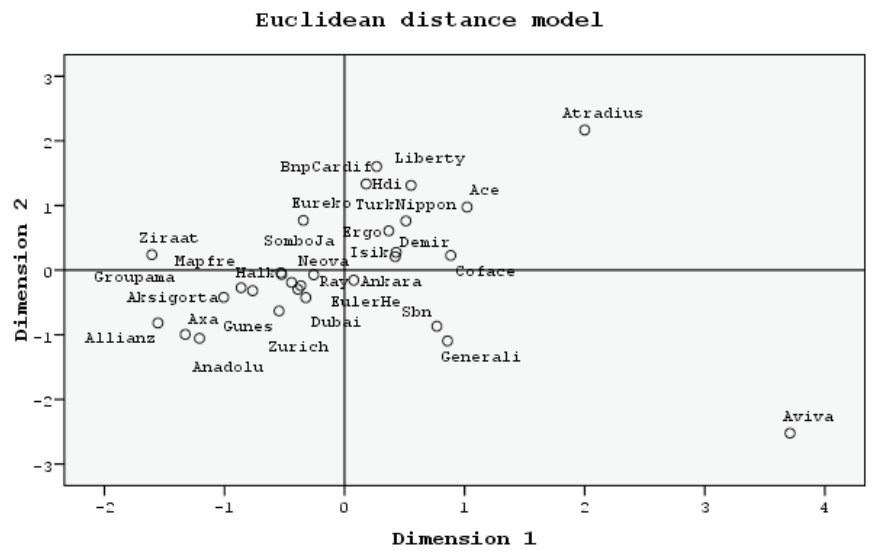

Figure 4: MDS of 30 Turkish Non-life Insurance Companies in 2014

Atradius is the company with most unsuccessful performance in 2014. Aviva and Atradius are in a farther position from other companies. It may be due to the decline of Aviva to rank 16 from rank 11. Comments for Aviva are similar to comments for Dubai in 2010 and explanation of dimensions effects the location of companies. Dimension 1 explains $36 \%$ and dimension 2 explains $29 \%$ of performance as to results of PCA. According to dimension 2 Generali and Aviva has similar performance. Successful companies such as Axa, Anadolu, Aksigorta and Allianz are at same location according to Figure 4 that show the MDS graph for 2014.

\section{Conclusion}

In this study, performance of non-life insurance companies operating in Turkey between 2010 and 2014 are evaluated using multivariate statistical methods such as PCA and MDS. PCA is used as a method of measuring the performance by weighted average of new components. Companies are ranked according to PCA scores, and results are supported by rank correlation matrix. Relations between companies are investigated by MDS. Using these study non-life insurance companies can compare themselves with other companies. Companies can do some modifications on their own resources and on their assets to operate more efficiently.

In the present paper, variables are selected according to literature review. For a more detailed study before multivariate analysis, variables can be selected using some statistical methods such as panel data analysis. Also only two multivariate methods and rank correlation matrix are used in the study. The study can be developed using different methods, methods can be combined for performance analysis and the results of methods can be compared. 


\section{References}

DENUIT, Michel, DHAENE, Jan, GOOVAERTS, Marc and KAAS, Rob, (2006) "Actuarial Theory for Dependent Risks: Measures, Orders and Models", John Wiley \& Sons.

HAO, James, C.J. and CHOU, Lin-Yhi, (2005) “The Estimation of Efficiency for Life Insurance Industry: The Case of Taiwan", Journal of Assian Economics 16, 847-860.

HARTON, Kane, (2010) "Scale Advantage-Using Data Envelopment Analysis to Detect Economies of Scale in the Insurance Industry", Proocedings of the 45th Annual Conference of the ORSNZ, November.

HO, Chien-Ta Bruce and WU, Desheng Dash, (2009) "Online Banking Performance Evaluation Using Data Envelopment Analysis and Principal Componenrt Analysis, Computers \& Operations Research 36, 6, 1835-1842.

MASHHADIFARAHANI, Omid, REZANI, Narges and HATAMI-SHIRKOUHI, Loghman, (2013) “A combined Principal Component Analysis-Regression Analysis Model to Study the Effect on Technical Efficiency of Bad Loans in Bank Industry”, Tecnicki Vjesnik 20, 6, 1071-1075.

RENCHER, Alvin, C., (2002) "Principal Component Analysis", Methods of Multivariate Analysis, Second Edition, John Wiley and Sons, 380-407.

SHANMUGAM, Ramalingam and JOHNSON, Charles, (2007) "At a Crossroad of Data Envelopment and Principal Component Analyses”, Omega 35, 351-364.

TATLIDİL, Hüseyin, (2002) “Uygulamalı Çok Değişkenli İstatistiksel Analiz”, Akademi Matbaası, Ankara.

TONE, Kaoru and SAHOO, Biresh, K., (2005) "Evaluating Cost Efficiency and Returns to Scale in the Life Insurance Corporation of India Using Data Envelopment Analysis”, Socio-Economic Planning Sciences 39, 261-285.

WANG, Fu-Kwun and DU, Timon, C., (2000) "Using Principal Component Analysis in Process Performance for Multivariate Data”, Omega 28, 185-194.

YANG, Zijiang, (2006) "A Two-Stage DEA Model to Evaluate The Overall Performance of Canadian Life and Health Insurance Companies", Mathematical and Computer Modelling 43, 7, 910-919.

ZHONGSHENG, Liu and DONG, Li, (2008) "Scale Expanding and Efficiency Improvement of Commercial Banks of China”, Processing of International Symposiums on Information, ISIP, 705-709.

ZHU, Joe, (1998) "Data Envelopment Analysis vs. Principal Component Analysis: An Illustrative Study of Economic Performance of Chinese Cities", European Journal of Operational Research, 111(1), 5061.

Internet References

https://www.hazine.gov.tr/ 